\title{
Growth Performance of Arrivals and Prices of Sorghum, Tur, Soybean, Chickpea and Bajra in Ahmednagar District, India
}

\author{
D.J. Navasare ${ }^{1 *}$, D.S. Perke ${ }^{2}$ and R.D. Shelke ${ }^{3}$ \\ Department of Agricultural Economics, Vasantrao Naik Marathwada Krishi Vidyapeeth, \\ Parbhani (M.S.), India \\ *Corresponding author
}

\begin{tabular}{|l|}
\hline Ke y w or d s \\
Arrival, Prices, \\
Growth \\
performance
\end{tabular}

Ahmednagar district is selected for present studies. The price of agricultural commodities assumes great significance from producer's as well as consumer's point of view. It is said that prices are mirror of economy of the country. The purpose of the present study is to examine the behaviour of fluctuations in prices and arrivals of Sorghum, Tur, Soybean, Chickpea and Bajra which are selected for study in APMC market in of Ahmednagar district. In Ahmednagar market arrivals of different agricultural products are in good quantity as compared to other markets. This market was selected due to the availability of continuous time series data for the research period. Five agricultural commodities are selected for present study i.e. from the sorghum, Tur, Soybean, Chickpea and Bajra. It was intended to collect for 12 years data from all four APMC of Ahmednagar district for selected agricultural commodities (2005-06 to 2016-17). The analysis of compound growth rate reveals that the growth rates of arrival and prices of overall period was positive and significant. In Ahmednagar APMC the highest growth rates were noticed in the soybean i.e. 161.82 per cent and lowest growth rate were noticed in the Bajra i.e. -32.24 per cent per year. In Karjat APMC the highest growth rates were noticed in the Sorghum i.e. 0.46 per cent and lowest growth rate were noticed in the Bajra i.e. -32.71 per cent per year, respectively. The prices of Sorghum, Tur, Soybean, Chickpea and Bajra increased significantly during the period under study. The inverse relationship between arrivals and prices was noticed for Sorghum, Tur, Soybean, Chickpea and Bajra which indicated that the increase in arrivals lowered the prices of these commodities.

\section{Introduction}

The APMCs were established by state government for regulating the marketing of different kinds of agricultural produce. The market information relating to market prices and arrivals over a period of time helps the cereal growers to take decision about the future production pattern and sale of agricultural commodities in the market during specific period. The price of agricultural commodities assumes great significance from producer's as well as consumer's point of view. It is said that prices are mirror of economy of the country. The purpose of the present study is to examine the behaviour of 
fluctuations in prices and arrivals of Sorghum, Tur, Soybean, Chickpea and Bajra which are selected for study in APMC market in of Ahmednagar district.

Agriculture sector in India has become an important component of the Indian economy and also it is said to be the biggest business of the world. Agriculture is the backbone of the Indian economy but, in real terms the farmer does not get proper returns from his investment. The variation in prices of agriculture commodities has been one of the major factors affecting the income levels of the Indian farmers. Due to increased agricultural production every year, the arrivals in the market also increased and prices also increased along with time. Normally every year increasing trend is seen in arrivals and prices of agricultural commodities.

\section{Materials and Methods}

The data in respect of arrivals and prices were collected from this record maintained by all four Agriculture Produce Market Committees (APMC) of Ahmednagar district. The monthly arrival and prices of selected agricultural commodities was recorded by market committee (APMC) of Ahmednagar district and the same was used for this study. Five samples of producer, wholesaler and retailer from all four selected markets and the information for the last 12 years (2005-06 to 2016-17) were collected by personally contacting them.

\section{Analytical tools}

Performance of arrival and prices of selected agricultural commodities in Ahmednagar district

The performance of arrival and prices of selected agricultural commodities was examined by estimating, Growth rate of arrival and prices.

\section{Estimation of growth rate}

The growth rate in arrival and prices were studied by estimating compound growth rate at different rate. Compound growth rates were estimated. The growth rate was estimated using following model.

\section{Compound growth rate}

$\mathrm{y}=a b^{\mathrm{t}}$

Where,

$\mathrm{y}=$ Yearly Arrival / Prices respectively,

$\mathrm{a}=$ Intercept,

$\mathrm{b}=$ Regression coefficient,

$\mathrm{t}=$ Time variable,

From the estimated function, the compound growth rate (CGR) was calculated for the study.

$\mathrm{CGR}=[$ Antilog $(\log \mathrm{b})-1] \times 100$

\section{Results and Discussion}

Growth performance of arrivals and prices of Sorghum, Tur, Soybean, Chickpea and Bajra in Ahmednagar district

In this study, the growth in arrivals and prices of Sorghum, Tur, Soybean, Chickpea and Bajra were estimated using compound growth rates as indicated in the methodology chapter. In this analysis, the general growth performance of arrivals and prices in Ahmednagar district were examined by fitting exponential growth function with time normalization on arrivals and prices.

The growth performance of Sorghum, Tur, Soybean, Chickpea and Bajra pertaining to the study period (2005-06 to 2016-2017) is discussed separately for each tehsil as under. 
Growth performance of arrivals and prices in Ahmednagar APMC

The growth performance of Ahmednagar APMC in arrivals and prices pertaining to study period was presented in the Table 1 . The results indicated that during the study period, all crops under study have registered negative growth rates in arrival of Ahmednagar APMC except Sorghum and Soybean crop and are statistically significant at 1 per cent and 5 per cent level of significance except Sorghum and Tur crop. The highest growth rates were noticed in the soybean i.e. 161.82 per cent and lowest growth rate were noticed in the Bajra i.e. -32.24 per cent per year.

The table revealed that during the study period, almost all crops in under study have registered positive growth rates in prices of Ahmednagar APMC. During the entire study period the highest increase in growth rates were noticed in the Soybean, Tur, Bajra, Sorghum and chickpea i.e. 54.88, 29.42, 23.59 , 22.74and 19.95 per cent per year, respectively.

Growth performance of arrivals and prices in Jamkhed APMC

The growth performance of Jamkhed APMC in arrival and price pertaining to study period was presented in the Table 2. It shows that during the study period, all crops under study have registered positive growth rates in arrival of Ahmednagar APMC except Tur and Chickpea crop and are statistically non significant except Sorghum are statistically significant at 1 per cent level of significance. The highest growth rates were noticed in the Sorghum i.e. 42.23 per cent and lowest growth rate were noticed in the Chickpea i.e. -22.91 per cent per year.

It revealed that during the study period, almost all crops in under study have registered positive growth rates in prices of Jamkhed APMC. During the entire study period the highest increase in growth rates were noticed in the Soybean, sorghum, Bajra and Tur i.e. 27.35, 23.31, 22.74 and 16.68 per cent per year, respectively. Except Chick pea crop are statistically non-significant.

\section{Growth performance of arrivals and prices in Shrigonda APMC}

The growth performance of Shrigonda APMC in arrival and price pertaining to study period was presented in the Table 3. The results indicated that during the study period, all crops under study have registered positive growth rates in arrival of Shrigonda APMC except Tur and Bajra crop and all are statistically non-significant. The highest growth rates were noticed in the Sorghum i.e. 8.89 per cent and lowest growth rate were noticed in the Tur i.e. -22.55 per cent per year, respectively.

Table.1 Growth performance of arrivals and prices in Ahmednagar APMC

\begin{tabular}{|c|c|c|c|c|c|c|}
\hline \multirow{2}{*}{ Crop } & \multicolumn{3}{|c|}{ Arrivals } & \multicolumn{3}{c|}{ Prices } \\
\cline { 2 - 8 } & CGR (\%) & SE & 't' Value & CGR (\%) & SE & 't' Value \\
\hline Sorghum & $0.23^{\mathbf{N S}}$ & 0.03 & 0.029 & $22.74^{* *}$ & 0.02 & 5.277 \\
\hline Tur & $-2.95^{\mathbf{N S}}$ & 0.04 & -0.333 & $29.42^{* *}$ & 0.02 & 5.772 \\
\hline Soybean & $161.82^{* *}$ & 0.11 & 3.661 & $54.88^{* *}$ & 0.06 & 3.247 \\
\hline Chickpea & $-21.30^{*}$ & 0.05 & -2.311 & $19.95 * *$ & 0.02 & 3.990 \\
\hline Bajra & $-32.24 * *$ & 0.04 & -4.615 & $23.59 * *$ & 0.005 & 18.60 \\
\hline
\end{tabular}

(Note: **significance at $1 \%, *$ significance at $5 \%$ ) 
Table.2 Growth performance of arrival and price in Jamkhed APMC

\begin{tabular}{|c|c|c|c|c|c|c|}
\hline \multirow{2}{*}{ Crop } & \multicolumn{3}{|c|}{ Arrivals } & \multicolumn{3}{c|}{ Prices } \\
\cline { 2 - 8 } & CGR (\%) & SE & 't' Value & CGR (\%) & SE & 't' Value \\
\hline Sorghum & $42.23^{* *}$ & 0.01 & 14.04 & $23.31^{* *}$ & 0.02 & 5.465 \\
\hline Tur & $-4.72^{\mathbf{N S}}$ & 0.05 & -0.438 & $16.68^{*}$ & 0.03 & 2.504 \\
\hline Soybean & $16.41^{\mathbf{N S}}$ & 0.05 & 1.385 & $27.35^{* *}$ & 0.02 & 5.222 \\
\hline Chickpea & $-22.91^{\mathbf{N S}}$ & 0.08 & -1.429 & $11.94^{\mathbf{N S}}$ & 0.05 & 1.005 \\
\hline Bajra & $12.20^{\mathbf{N S}}$ & 0.03 & 1.519 & $22.74 * *$ & 0.01 & 10.10 \\
\hline
\end{tabular}

(Note: **significance at $1 \%, *$ significance at $5 \%$ )

Table.3 Growth performance of arrival and price in Shrigonda APMC

\begin{tabular}{|c|c|c|c|c|c|c|}
\hline \multirow{2}{*}{ Crop } & \multicolumn{3}{|c|}{ Arrivals } & \multicolumn{3}{c|}{ Prices } \\
\cline { 2 - 8 } & CGR (\%) & SE & 't' Value & CGR (\%) & SE & 't' Value \\
\hline Sorghum & $8.89^{\mathbf{N S}}$ & 0.03 & 1.221 & $19.12^{* *}$ & 0.02 & 3.698 \\
\hline Tur & $-22.55^{\mathbf{N S}}$ & 0.12 & -0.922 & $44.54 * *$ & 0.02 & 7.276 \\
\hline Soybean & $5.20^{\mathbf{N S}}$ & 0.14 & 0.162 & $15.08^{\mathbf{N S}}$ & 0.04 & 1.532 \\
\hline Chickpea & $0.69^{\mathbf{N S}}$ & 0.02 & 0.159 & $16.41^{* *}$ & 0.02 & 3.409 \\
\hline Bajra & $-21.48^{\mathbf{N S}}$ & 0.09 & -1.209 & $19.40^{* *}$ & 0.01 & 14.12 \\
\hline
\end{tabular}

(Note: **significance at $1 \%$, *significance at $5 \%$ )

Table.4 Growth performance of arrivals and prices in Karjat APMC

\begin{tabular}{|c|c|c|c|c|c|c|}
\hline \multirow{2}{*}{ Crop } & \multicolumn{3}{|c|}{ Arrivals } & \multicolumn{3}{c|}{ Prices } \\
\cline { 2 - 8 } & CGR (\%) & SE & 't' Value & CGR (\%) & SE & 't' Value \\
\hline Sorghum & $0.46^{\mathbf{N S}}$ & 0.03 & 0.077 & $19.22^{* *}$ & 0.02 & 3.725 \\
\hline Tur & $-32.55^{\mathbf{N S}}$ & 0.10 & -1.694 & $21.62^{* *}$ & 0.02 & 3.481 \\
\hline Soybean & $-22.20^{\mathbf{N S}}$ & $0 . .08$ & -1.296 & $4.23^{\mathbf{N S}}$ & 0.03 & 0.607 \\
\hline Chick pea & $-27.89^{*}$ & 0.07 & -2.062 & $9.90^{\mathbf{N S}}$ & 0.03 & 1.130 \\
\hline Bajra & $-32.71^{*}$ & 0.07 & -2.474 & $18.58^{* *}$ & 0.01 & 11.82 \\
\hline
\end{tabular}

(Note: **significance at $1 \%$, *significance at $5 \%$ )

Among that during the study period, almost all crops in under study have registered positive growth rates in prices of Shrigonda APMC. During the entire study period the highest increase in growth rates were noticed in the Tur, Bajra, Sorghum, Chickpea and Soybean i.e. 44.54, 19.40,19.12, 16.41 and 15.08 per cent per year, respectively.

\section{Growth performance of arrivals and prices in Karjat APMC}

The growth performance of Karjat APMC in arrival and price pertaining to study period was presented in the Table 4. It shows that during the study period, all crops under study have registered negative growth rates in arrivals of Karjat APMC except Sorghum crop and are statistically non-significant except Chickpea and Bajra are statistically significant at 5.00 per cent level of significance. The highest growth rates were noticed in the Sorghum i.e. 0.46 per cent and lowest growth rate were noticed in the Bajra i.e. -32.71 per cent per year respectively.

It revealed that during the study period, almost all crops in under study have 
registered positive growth rates in prices of Karjat APMC. During the entire study period the highest increase in growth rates were noticed in the Tur, Sorghum, Bajra, Chickpea and Soybean i.e. 21.62, 19.22, 18.58, 9.90 and 4.23 per cent per year, respectively.

The conclusions of the study are as follows:

The significant increase in arrivals of soybean and pigeon pea whereas; significant decrease in arrivals of Jowar was noticed in the APMC, Ahmednagar.

The prices of Sorghum, Tur, Soybean, Chickpea and Bajra increased significantly during the period under study.

The inverse relationship between arrivals and prices was noticed for Sorghum, Tur, Soybean, Chickpea and Bajra which indicated that the increase in arrivals lowered the prices of these commodities.

\section{References}

Benke, S.R., Gholap, V.B. and Gade, P.V. (2016) An economic analysis of green gram arrivals and price behaviour in Akola district (Akola APMC) of Maharashtra, International Research Journal of Agricultural Economics and statistics, 7(2): 198-202.

Daundkar, K.S. and S.K. Bairagi, (2015) Trends in arrivals and prices of onion in Ahmedabad (Gujarat) market, International Journal of Commerce and Business Management, 8(1): 117119.

Hile, R. B., D. J. Sanap and D. B. Yadav, (2017) Trends in Arrival and Prices of Major Agricultural Commodities in APMC, Satara of Western Maharashtra, International Journal of Tropical Agriculture, 35(2): 02548755.

Kerur, N. M., B. Banakar, H. S. Vijaya Kumar, L. Manjunath And $\mathrm{H}$. Basavaraj, (2008) Performance Analysis of Regulated Markets in Karnataka, Karnataka Journal of agricultural Science, 21(1): 74-77.

Salunkhe, A. A. (2010) Price behaviour and price forecasting of selected crops of Akola District. Unpublished M.Sc. (Agri.) thesis submitted to Dr. P.D.K.V, Akola (M.S.),:79

Thakare, H.P., Daundkar, K.S., Rathod, Savita R. and Bondar, Uttam S. (2017) Changes and trends in arrival and prices of agricultural commodities in APMC Kolhapur market, International Research Journal of Agricultural Economics and statistics, 8(1): 26-30.

Verma, D.K.,Latika S., Hari S., Jitendra S. (2016) A Study on Price Behaviour of Soybean in Southern Rajasthan, Economic Affairs, 62(3): 531-535.

\section{How to cite this article:}

Navasare, D.J., D.S. Perke and Shelke, R.D. 2018. Growth performance of arrivals and prices of Sorghum, Tur, Soybean, Chickpea and Bajra in Ahmednagar district, India. Int.J.Curr.Microbiol.App.Sci. 7(07): 3697-3701. doi: https://doi.org/10.20546/ijcmas.2018.707.427 